\title{
The Changing Status and Role of Penghulu in the System of Nagari Governance
}

\section{Maulid Hariri Gani and Andree Harmadi Algamar}

Institut Seni Indonesia Padang Panjang and Institut Pemerintahan Dalam Negeri

\section{Abstract}

Introduction. This research is aimed at analyzing the transformation of the role of penghulu and nagari institution in Minangkabau which based on regional regulation. The greatness of the role and responsibility of a penghulu in the past time required big responsibility and act in accordance with what the society needs. Therefore, by shifting of the leadership role of a penghulu, it is important to be known, how far the role of penghulu at this time. Method This research is done by qualitative approach, the data obtained by observation and in-depth interview to the informant that has been chosen. Existing data are examined in depth and traced, and analyzed including

Corresponding Author: Maulid Hariri Gani maulidharirigani@yahoo.co.id

Received: 18 January 2019 Accepted: 24 March 2019 Published: 31 March 2019

Publishing services provided by Knowledge E

(c) Maulid Hariri Gani and Andree Harmadi Algamar. This article is distributed under the terms of the Creative Commons

Attribution License, which permits unrestricted use and redistribution provided that the original author and source are credited.

Selection and Peer-review under the responsibility of the First ELEHIC Conference Committee. possible relationships between categories. Results. The result of this research shows that some changes had happened in relation to the fading of the role of penghulu in the community. In the past a penghulu had responsibility to protect his nice/nephew 'kemenakan' and his clan 'kaum', but nowadays his role has been replaced by their own parent. Penghulu is not considered as a sacred figure by his kemenakan and his kaum. For creating the participation of penghulu actively in nagari government system and joining with other elements in the community, Lembaga Tinggi Nagari are formed as judicial element in the nagari government. As the result, there is disharmony in the government itself because there is influential competition and powerness in the community. This can be said that the nagari system government reinstitution can be happened because there is adaptation towards the change itself as a dynamic society and Minangkabu people consider a change as something usual in understanding of Minangkabau community that everything is everlasting. The community still consider penghulu as the community leaders, eventhough they have less function today.

Keywords: social change, nagari government, and penghulu.

\section{Introduction}

The form of government in Minangkabau that has long been known to the public is the form of Nagari government. This institution has evolved for centuries, long before Dutch colonization came to Indonesia. Within a relatively long period of time, the Minangkabau 
people have been living under the leadership of organized penghulu community in customary density institutions, which are present in every Nagari.

However, in 1979 the central government issued Law no. 5 on Village Administration, where the lowest government unit in all of Indonesia is uniformed into the Village and removes all the lowest government units available in each region of Indonesia, including Nagari in Minangkabau West Sumatra. In this case, the West Sumatra Local Government responded immediately to the change by making or choosing Jorong as the lowest government unit, rather than Nagari.

Chosing Jorong to become a Village, rather than Nagari, because it is more on the calculation of income summary in the economic sense, where the central government at that time will only provide assistance in the form of village development aid assistance, in every lower government unit in the village area. If Nagari is listed as the lowest government, then the number is only 543 pieces, which means the amount of aid is not too big, so Jorong recorded as the lowest government, so the number reaches 3,139 villages and 406 urban villages. In fact, Jorong is only part of the administration of the Nagari government, which does not have sufficient requirements to become a separate territory of government. Jorong in West Sumatra at that time only had a population of 500-1000 people, while numbering above 3000 people no more than 100 villages, whereas the Minister of Home Affairs Regulation no. 4 year 1981 sets the minimum population of a village is 2,500 people [1].

A Nagari has institutional and customary institutions, and therefore as an effective government unit, when the existing nagari are eliminated, the principles of integrating adat governance units and formal government that have been characteristic of the system Nagari government are disappeared. The Nagari gathers the knots of power and authority. Nagari is not only a territorial unit and a formal governmental unit, and has the power and authority of power delegated from above, but Nagari is also customary union which is autonomous and independent in which the community is involved in it [2].

Although the West Sumatra Local Government tries to maintain the existence of Nagari by expelling Perda no. 3 of 1983 on the position of Nagari as a unit of customary law community, but in fact Nagari existence remains difficult to maintain, because basically the government affairs and affairs in the unity of indigenous people is a unity that is interconnected with each other.

The changing from Nagari to the Village is not just a naming change, but also the system, orientation and philosophy. Nagari is also a "state" in a miniature sense. The order at Nagari level as "small republics" is self-contained, autonomous and self-fixing. 
In addition to the legislative, executive, and judicial elements in the order of Nagari's governmental apparatus, it is also a holistic unity for the various sets of other sociocultural structures. While the Village shows the opposite picture, which is the lowest administrative unit of a bureaucratic system, as well as the spearhead of a system of governance entirely controlled from above, which is structurally-vertical to the center. The village is oriented only on "compliance" and "uniformity", not on "independence" and "diversity" [2].

In 1999, The central government issued Law no. 22 on Regional Government, in which it regulates regional authority to organize regional autonomy. UU no. 22 of 1999 was immediately welcomed by the West Sumatra Regional Government with Local Regulation no. 9 of 2000 on the Basic Provisions of the Nagari Government. In the law there is a unity of customary law community within West Sumatera Province, which consists of a set of tribes whose territory has certain limits, owns own property, is entitled to arrange and manage the household, and elect its government leader.

For Minangkabau society, Tribe and Nagari people have a very important meaning, because in the kinship system of Minangkabau people the tribe is the smallest unit, while the largest unit is a collection of senagari men [3]. To organize the life of the Minangkabau community within the largest unit, consisting of at least four tribes, the Nagari system of government grew and developed in the midst of the life of the community.

Basically, Nagari's position at that time was a territory which had full autonomy under the leadership of the chiefs who were organized in the Nagari Customary Density, which administered according to the word mufakat or wisdom alue jo patuik, (wisdom of groove with propriety) even relationship between Nagari arranged and executed by the Nagari Customary Density [4]. Between one nagari and the other nagari there is no formal structural linkage, where each nagari stands alone and separated from other villages [5].

A Nagari is led by a community-elected Wali Nagari, and is endorsed by the Nagari People's Legislative Assembly (BPRN), while the existing of the Jorong is led by Wali Jorong. Inside Jorong there are tribes, where each tribe is led by a Tribal Pengusul usually called Penghulu Pucuk (Koto Piliang Harp) or Penghulu Tuo (Bodi Caniago Aligned). The Collective Leadership of the first four tribes is called Penghulu Andiko (Andika, meaning the main one). The former leader of a tribe who had split from the first tribe was called Penghulu Payung, while those who divide themselves from their sides, or disputes in the struggle for the office of the penghulu are called Penghulu Indu. An Adulterer is assisted by Panungkek (Supporters), who can represent the Penghulu if absent, but in Nagari density he is only a listener and asked for opinions when asked. 
From the description above it can be concluded that the existence of a Penghulu in its tribe has a huge role in the motion of a Nagari government, in addition of course the customary institutions that have been formed. The leadership of a Penghulu participates in influencing the success or failure of the Nagari Government system itself, therefore it is necessary to know and be described further how the role and form of leadership itself. The role here is the behavioral patterns that are considered appropriate for a person performing actions in his social capacity within a certain framework [6]. As it means, how a person acts in his social environment depends on what role he or she has in his social status.

One's own role is related to his status in society. It is seen that status as a right and a duty in a reciprocal role relationship (the position or social capacity one has in a particular framework) [6]. As a penghulu, then his status will also be associated with the authority he has as a leader. The authority in this case is defined as the right that has been established in the social order to establish the policy, determine the decisions and settle the existing contradictions [7]. In other words, a person who has a status of penghulu in principle also has the authority to act as a person who leads or guides the crowd.

Because of greatness of the role and responsibility of a penghulu, thus required a penghulu that can act in accordance with what is desired by its citizens. From that case, the author will see how the leadership role of a penghulu in tribe and in his nagari. The role of Penghulu is central, thus it required in the middle of the community, so that any problems that exist in the community can immediately overcome. Some of these questions came to the light, for the leadership of the Adat and the Nagari Adat Institutions had been "long gone" from the memory or the life of the community, and this could have given birth to a new generation in Minangkabau society, which may have experienced shifts in understanding with previous generations with that nagari itself.

\section{Method}

This research was conducted in Nagari Kamang Hilia, Kamang Magek District, Agam District Level II. The selection of the research sites is based on subjective and administrative considerations. This choice is inseparable from the history of Nagari itself, which is one of the oldest Kanagarian in Agam Regency. In addition, Nagari Kamari Hilia selected as the location of research, it is also on the consideration of the existence of the family of the writers, which is expected to facilitate the search data required later. This research is done by qualitative approach, the data obtained by observation and in-depth interview 
to the informant that has been chosen. Existing data are examined in depth and traced, and analyzed including possible relationships between categories. All of this is seen as an integrated form of unity [8].

\section{Results and Discussion}

In carrying out the role of a penghulu, a nagari guard and a nagari high institution, there will be many adaptations and changes. The change of the role of a penghulu in the nagari government system begins with the issuance of Law no. 22/1999 on Regional Government by the central government, which regulates regional authority to organize regional autonomy. The West Sumatra regional government itself then complained Regional Regulation no. 9/2000 on the Basic Provisions of the Nagari Government. The enthusiasm of this local government was directly responded by the Regional Government of Agam Regency by issuing the Local Regulation no. 31/2001 on the Government of Nagari, in which there is a unity of customary law community consisting of several tribes, having a certain territory of its limits, having its own property, is entitled to administer and manage its own household, and elect its leadership.

\subsection{The changing status and the role of Penghulu}

Keesing defines status as a right and a duty in the reciprocal relationship (the position or social capacity that a person possesses within a certain framework), while the role is defined as the patterns of one's behavior in performing certain actions in its social capacity. For example, a person who has status as a Sutan, in the degree stratum is not the highest existing title, but the title of Datuk is the highest, which of course has its own specialties in the community, for example to take precedence in a certain activity. However, if a person who holds Sutan title can achieve the highest social status within his or her family, for example being a Wali Nagari, then automatically concerned should act as a person deemed worthy to be elded or precedence in his or her people. All this is of course also related to the status of what he was living at that time, because the status itself relates to the authority it has in its social capacity. This can be seen in Herman St. Majo Indo, Wali Nagari Kamang Hilia. In the Minangkabau customary law, Herman St. Majo Indo is not a person who takes precedence one step and elevated seranting in all activities of community activities, because the title he held is a title sutan, not a datuk. However, due to his position as Nagali Wali Kamari Hilia, the role he must perform must be in accordance with his status as a wali nagari, and he has a pre-determined authority 
to perform his role as guardian of the nagari. On the contrary, people also indirectly position themselves as people who deserve to take precedence one step and elevated sekanting in all activities of social activities, because of its status as wali nagari.

The authority itself into three parts, there are charismatic authority, traditional authority, or rational / legal authority [9]. Starting from the three forms of authority described by Weber above, then the status and role that exist in a penghulu depends on what role he was living at that time. On the other hand, a penghulu positions itself as a mamak for his family (traditional authority), but on the other hand he can position himself as a penghulu in the nagari government system (rational / legal authority).

Sabarun Dt. Singo Gayua, on the one hand, he is a mamak or penghulu in his people because of his position as a datuk (traditional authority). But on the other hand, he is an official within the nagari government structure as Vice Chairman of the Nagari Customary Density (rational / legal authority). Here, Sabarun Dt. Singo Gayua must be able to position himself, where his status as a mamak in his people, and where his status as a penghulu in Indigenous Density Nagari.

The role run by a penghulu, ideally (traditional authority) pay more attention to his nephew than his own son. However, in line with the times and the high mobility of the Minangkabau community, whether in the field of education, economics and so on, the role attached to penghulu himself also undergo changes. Moreover, the Minangkabau community and culture itself gives the place of change.

The philosophy of the Minangkabau people who read Once Aia Gadang, Once the Tapian Barubah (once the flood, once the bath changed) gave the meaning that nothing is everlasting in the universe, he always undergoes change and change itself is something natural, as nature it always changes too. The following Pantun probably will be able to illustrate how a change is commonplace among Minangkabau people [10]:

Kayu pulai di Koto Alam

Batangnya sandi-basandi

Jikokpandai dalam alam

Patah tumbuah hilang baganti.

Kayu pulai di Koto Alam

Batangnya sendi-bersendi

Kalau pandai dalam alam

Patah tumbuh hilang berganti. 


\author{
Wood pulai in Koto Alam (city of nature) \\ The trunks are joints-jointed \\ If clever in nature \\ whatever lost will be replaced.
}

Nature continues to live, even if there is a broken. For example a tree, then it will continue to grow even though the branch is broken. This attitude is the attitude of the Minangkabau people who are always optimistic, as long as able to adjust to the nature and environment. Further Sairin says: "Minangkabau people are a very dynamic and adaptable society to the changing environment. What is considered good to have, then taken over and adapted to Minangkabau culture" [11].

Changing that occur in Minangkabau society today may not even be imagined by the Minangkabau community itself before. The change can be seen with the fading role of the penghulu in society.In general view, nowaday a penghulu is no longer something sacred to his kemenakan (nephew) or his people. Even in some cases the role of penghulu has begun to be abandoned, suppose the penghulu no longer a place to ask, while on the other hand kemenakan (nephew) or the people of the penghulu no longer see that the penghulu is responsible for maintaining themselves.

This can be exemplified in one of the tribes in Nagari Kamang Hilia, where the penghulu of the tribe can not play the role as the status as a penghulu, due to the sick condition. How could the status of the penghulu here be a sacred status for his kemenakan (nephew) or his people, while he himself can not play the role he should be performing.

All of the above are caused by many things, both internal and external. From within the penghulu itself, knowledge (both formal and informal) is very limited in the midst of the modern world today, making the penghulu all-behind knowledge of the kemenakan (nephew) or his people. A penghulu who used to be positioned as a Banyan tree in the middle of the field, now is no longer standing alone in the middle of the field, even the growing banyans that has many and even greater than the banyan (penghulu) itself. This can be seen by the large percentage of penghulu who only finish primary school education which reaches approximately $40 \%$ (assuming the total number of penghulu reached more than 97 people), First Level School more or less 10\% and School of Advanced Level about $25 \%$. While reaching the education level only $25 \%$. This shows that the number of existing principals only completes formal primary school education (40\%), and only $25 \%$ (college level) can reach the highest level. 
From the $25 \%$ of the penghulu attending the college education level, only 1 (one) person (-100) lived in Nagari Kamang Hilia, the rest live outside Nagari Kamang Hilia. From the total number of penghulu, approximately $20 \%$ of them are also not in Nagari Kamang Hilia due to work reasons, whether as a government employee, private employee or profession as a trader. Sjahmunir, himself argues that the existence of a penghulu who is constantly in the midst of society is very important that all problems that arise can be resolved immediately [12]. Only now, the meeting between the penghulu and his people is more due to the marriage ceremony, death events, and affairs that are truly essential so that the presence of the penghulu is really needed his presence, for example there was a dispute between his kemenakan (nephew).

Besides it caused by the knowledge factor above, the existing penghulu are not able to maintain their authority, image and role in the midst of society. A penghulu who in the tenet of the Minangkabau people is one who must take a step forward and be elevated at every opportunity, but in reality does not have to be so. Quite a few of penghulu have the occupations, where the value of his work is below the value of the work of his kemenakan (nephew) or his own people. For example the penghulu works as a farmer, while his nephew or his people are government employees and have a pretty good position. It is an enormous obstacle for the penghulu to apply the rules to be determined, because socially, economically as well as education, the penghulu is under the child of his kemenakan (nephew).

This example can be described as follows: Suppose the leader in A is a farmer with only elementary school education. The land area he owns is not more than 0.5 hectares. If rounded earnings in one month more or less Rp. 300,000; while the penghulu itself must support his wife and also three children who all are studying, then the money Rp. 300,000 , it probably would not be enough for the penghulu for the needs of his household, and how might the burden will be added with his other kemenakan (nephews).

On the other hand, let's say one of the kemenakan (nephew) of the above penghulu has been able to live well by working as a lecturer at a college. The kemenakan (nephew) of this penghulu has completed his $\mathrm{S}-3$ education ( $\mathrm{PhD}$ education), with an income of approximately $\operatorname{Rp} 2,000,000$, - in one month. Socially, economically and educationally, the penghulu is far behind with his kemenakan (nephew), then how could the penghulu be able to further apply the things he should do (advise, protect, nurture and so on) to his kemenakan (nephew). While the kemenakan (nephew) itself has more value than the penghulu itself.

Sairin argues that the relation between the penghulu and his nephew or his people is due to the strengthening of the relationship between father and his son, where the 
tendency to live in the form of nuclear family relations in the household in Minangkabau can be strengthens, so the role of penghulu itself begins marginalized [11]. He exemplified in the world of education, where a child is indirectly forced by the rules to include his father's name in all activities, for example in the school report card. At the beginning of the birth of a child, to be recognized by the state, in making the birth certificate the father's name is included, not the name of the penghulu of his mother. The modern world indirectly also marginalizes the role of the penghulu against his people. The demands of life increasingly assume greater responsibility for a father to his children, so at the same time the attention to the kemenakan (nephew) begins to be neglected.

However, it does not mean that the existence of these chiefs has no meaning whatsoever in the life of society. The existence of the rulers is still needed, but the role it bears a little more began to shift from what was considered the ideal before. As a unifying figure of his people, the penghulu is still urgently needed. Penghulu still enough role in the customary events, for example in the marriage ceremony, the management of treasures and other things.

Here, the role of leader as a respected,honoured and influential person in the midst of society, so that his attitudes, behaviors and deeds are respected, obeyed and used as examples by society have begun to change. Penghulu likened kayu gadang di tangah padang, ureknyo tampek baselo, dahannyo tampek bagantuang, daunnya tampek balinduang, batangnya tampak basanda (a large wood in the middle of the field, its veins are crossed, its branch is a hanging place, its leaves are shelter, its trunk is leaning) a little more has begun to be questioned the truth, because it will feel very heavy carried by the penghulu because of its limitations. Not even the possibility of a penghulu busy thinking about his family's economy, and how the penghulu might be able to think of his people!

Muchlis St. The penghulu himself argues that a penghulu should consider in his people no longer in the narrow scope as it has been, where the penghulu only think of his tribe alone (although at some point this is still needed, for example in matters of marriage), but all the rulers in Nagari united, and focused more on solving the problems at the nagari level, together with the wali nagari. Some of the respondents whom I met agreed to call the penghulu in Nagari Kamang Hilia were peasants in mutual help, where with their limitations, all the limitations within these self-regulators could, by themselves, be solved. Do not let the title of penghulu only live on the title alone, he exists and lives in the community, but can not be empowered, because his authority has been lost in the environment that should respect him. 
Thus, here had begun a change of leadership that exists in the midst of society. Penghulu who previously became central figure in every activity of his people, began to shift to the role of parents of each child. It is very common, if the penghulu also prefer to think and advance his own children than his people, regardless of the limitations he has.

Institutionally (rational / formal), the status and role of a penghulu against the nagari government system is appreciated in the Nagari People's Legislative Assembly, the Council of Deliberation of Adat and Syara' Nagari, the Density of Adat Nagari, and the Nagari Ulama Council. In this nagari system, the tasks of the penghulu are dependent on their respective duties, such as giving inputs or considerations concerning adat matter to the wali nagari, if the wali nagari requires the considerations he desires.

\section{Conclusion}

UU no. 5/1979 on Village Governance is considered most of the people and the government of West Sumatra has turned off the role of customary institutions contained in the community, regardless of the cause of all this also due to mistakes of the West Sumatra Regional Government itself which previously established Jorong as Village instead of Nagari as the lowest government unit in society.

The reformation period revolved, which also affected the legislation products, where the central government issued Law no. 22/1999 on Regional Governments that regulate the implementation of regional autonomy. This law was followed by Perda no. 9/2000 by the Government of West Sumatra on the Basic Provisions of the Nagari Government. In addition, every district in West Sumatra also directly follow up the Law No. 22/1999 and Regulation no. 9/2000, including Agam Regency by issuing Perda no. 31/2001 on Nagari Government.

Restoring a system that is less than 20 years is no longer applied in society is not an easy matter. Changes within the 20-year span are inevitable, and that can not be avoided in the course of society's progress and development. The change can be seen with the growing role of penghulu in the community, where a penghulu no longer be something that is sacred to the nephew or his people. Even in some cases the role of the penghulu itself has begun to be abandoned, for example the penghulu is no longer a place to ask questions. While on the other hand, nephew or his people no longer see the penghulu responsible for maintaining themselves. The former leader of a central figure, began to shift to the role of their respective parents. The change itself is preceded by the changes occurring within the Minangkabau family, where the role of a father becomes 
more dominant than ever. Father is not the head of the family in Minangkabau adat law which embraces the matrilineal system, but only urang sumando or honorable guest in his wife's family. As urang sumando, he has no responsibility for his wife and children. He is only responsible to his kemenakan (nephews), because he is positioned as a mamak and or as a penghulu in his people.

Many reasons why the change of the role of a penghulu in the community, be it economic factors, education and so forth. Economic factors for example, especially with the increasing role of a father to finance all the needs of each household, so that his nephews are also indirectly been financed by his own parents.

Meanwhile, at the level of the nagari government, a penghulu positioned himself as the status of the nagari government. If his status as a representative of the Nagari Traditional Density Board, then the role he must perform is as a counselor to the wali nagari in the customs field. Similarly, if the status as a representative of the Majelis Ulama Nagari, then the role that is executed is as a religious guardian of the nagari counselor. The role of the penghulu here is a new role, where during the village administration the penghulu did not have formal institutions within the formal government structure. All this apart from the overlapping of roles between institutions with other institutions, such as the role of Indigenous Density Institution in maintaining and developing customary values of Minangkabau in the syariat of Islam, with the institution of Majelis Ulama Nagari which has the role of instilling Islamic faith in the middle the Nagari community.

Changes at the level of structure in Nagari Kamang Hilia have occurred, where the system of village administration has been replaced by the nagari government system. However, substantially the changes do not differ from each other, since the difference is only a mere naming difference from village government to nagari government. In order to impress the changes in the village administration, the traditional elements that are traditional institutions are made rational / formal elements within the nagari government, not more than that.

Judging from the above facts, it can be said back to the nagari system of government can be done because of the adaptation to change itself, let alone Minangkabau society is a dynamic society and see a change as something that is natural. The Minangkabau people understand that nothing is eternal in nature. Nevertheless, the people still regard the penghulu or nagari government institutions as their leaders, regardless of the shrinking role they currently occupy. Here, the role itself no longer stands on the ideal things as before (model for), but has undergone changes in accordance with the reality in the middle of society (model of). 


\section{References}

[1] Sampono, Damciwar Dt. Bagindo. (1990). "Dampak Perubahan Nagari Terhadap Pembangunan Pedesaan di Sumatera Barat", dalam Nagari, Desa dan Pembangunan Pedesaan di Sumatera Barat. Edi Utama (ed.). Yayasan Genta Budaya: Padang.

[2] Naim, Mochtar. (1990). "Nagari Versus Desa: Sebuah Kerancuan Struktural", dalam Nagari, Desa dan Pembangunan Pedesaan di Sumatera Barat. Edi Utama (ed). Yayasan Genta Budaya: Padang.

[3] Amir, MS. (1999). Adat Minangkabau: Pola dan Tujuan Hidup Orang Minang. Mutiara Sumber Widya: Jakarta.

[4] Hasbi, Mohammad. (1990). "Intervensi Negara Terhadap Komunitas Nagari di Minangkabau" dalam Nagari, Desa dan Pembangunan Pedesaan di Sumatera Barat. Edi Utama (ed.). Yayasan Genta Budaya: Padang.

[5] Naim, Mochtar. (1984). Merantau: Pola Migrasi Suku Minangkabau. Gadjah Mada University Press: Yogyakarta.

[6] Keesing, Roger M (1992). Antropologi Budaya: Suatu Perspektif Kontemporer. Erlangga: Jakarta.

[7] Soekanto, Soerjono. (1992). Sosiologi: Suatu Pengantar. Rajawali Pers: Jakarta.

[8] Moleong, Lexy J. (1994). Metodologi Penelitian Kualitatif. Remaja Rosdakarya: Bandung.

[9] Soekanto, Soerjono. (1992). Sosiologi: Suatu Pengantar. Rajawali Pers: Jakarta.

[10] Navis, A.A. (1986). Alam Terkembang Jadi Guru: Adat dan Kebudayaan Minangkabau. Gratitipers: Jakarta.

[11] Sairin, Sjafri. (2002). Perubahan Sosial Masyarakat Indonesia: Perspektif Antropologi. Pustaka Pelajar: Jogyakarta.

[12] Sjahmunir, AM. (1988). "Pergeseran Peranan Mamak Kepala Waris" dalam Firman Hasan (penyunting) Dinamika Masyarakat dan Adat Minangkabau. Pusat Penelitian Universitas Andalas: Padang. 